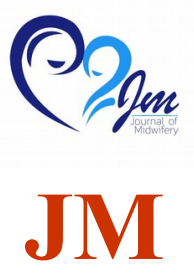

Volume 8 No. 1 (April 2020)

(C) The Author(s) 2020

\title{
EFEKTIFITAS PEMBERIAN AROMATERAPI LEMON TERHADAP PENURUNAN FREKUENSI EMESIS GRAVIDARUM PADA IBU HAMIL TRIMESTER I DI BPM INDRA ISWARI, SST, SKM, MM KOTA BENGKULU
}

\author{
EFFECTIVENESS OF LEMON AROMATERAPY PROVISION ON THE REDUCTION \\ OF GRAVIDARUM FREQUENCY IN TRIMESTER PREGNANT MOTHER I \\ IN BPM INDRA ISWARI, SST, SKM, MM BENGKULU CITY
}

\author{
YESI PUTRI, RONALEN BR. SITUMORANG \\ FAKULTAS ILMU KESEHATAN UNIVERSITAS DEHASEN BENGKULU \\ Email: putriyesi29@gmail.com
}

\begin{abstract}
ABSTRAK
Aromaterapi merupakan terapi modalitas atau pengobatan alternative dengan menggunakan sari tumbuhan aromaterapi murni berupa bahan cairan tanaman yang mudah menguap dan senyawa aroma terapi lain dari tumbuhan. Mual muntah (Emesis gravidarum ) keluhan paling sering terjadi pada ibu hamil sebesar 50-90\%, sebesar $2 \%$ berakhir menjadi mual muntah berlebihan (hiperemesis gravidarum) yang bisa membahayakan ibu maupun janin. Salah Satu terapi non farmakologi yang aman untuk diberikan pada ibu mual muntah selama kehamilan adalah aromaterapi lemon. Tujuan yang ingin dicapai dalam penelitian ini adalah untuk membuktikan pengaruh aromaterapi lemon dalam menurunkan mual muntah pada ibu hamil trimester I Mengetahui Efektivitas Pemberian Aromaterapi Lemon terhadap Penurunan Frekuensi Emesis Gravidarum pada Ibu Hamil Trimester I di BPM Indra Iswari, SST, SKM, MM. Metode yang digunakan pre eksperimental dengan desain One Group Pre-Post Test Design. Data dianalisis dengan menggunakan Wilcoxon Sign Rank Test dengan a =0,05. Kesimpulan dari penelitian ini adalah aromaterapi lemon secara bermakna mempunyai pengaruh dalam menurunkan emesis gravidarum pada ibu hamil trimester I.
\end{abstract}

Kata Kunci: Aromaterapi Lemon, Emesis Gravidarum

\begin{abstract}
Aromatherapy is a modality therapy or alternative treatment using pure aromatherapy plant extracts in the form of volatile plant liquid ingredients and other therapeutic aroma compounds from plants. Nausea vomiting (Emesis gravidarum) complaints most often occur in pregnant women by $50-90 \%$, amounting to $2 \%$ ends up becoming nausea excessive vomiting (hyperemesis gravidarum) which can harm the mother or fetus. One non-pharmacological therapy that is safe to give to nausea and vomiting during pregnancy is lemon aromatherapy. The aim of this research is to prove the effect of lemon aromatherapy in reducing nausea and
\end{abstract}


vomiting in first trimester pregnant women. Knowing the Effectiveness of Lemon Aromatherapy on Reducing the Frequency of Emesis Gravidarum in Trimester I Pregnant Women at BPM Indra Iswari, SST, SKM, MM. The method used is pre-experimental with the One Group Pre-Post Test Design. Data were analyzed using the Wilcoxon Sign Rank Test with $\mathrm{a}=0.05$. The conclusion of this study is that lemon aromatherapy has a significant effect in reducing emesis gravidarum in first trimester pregnant women.

\section{Keywords: Lemon Aromatherapy, Emesis Gravidarum}

\section{PENDAHULUAN}

Emesis terjadi pada $60-80 \%$ primigravida dan $40-60 \%$ multigravida. Seratus dari seribu kehamilan, gejala ini menjadi lebih berat. Perasaan mual ini disebabkan oleh karena meningkatnya kadar hormon estrogen dan hCG dalam serum. Pengaruh fisiologik kenaikan hormon ini belum jelas, mungkin karena sistem saraf pusat atau pengosongan lambung yang berkurang, sehingga menyebabkan mual muntah pada ibu hamil (Santi, 2013).

Emesis pada ibu hamil trimester pertama di masyarakat masih terjadi dan cara penanggulangannya sebagian besar masih menggunakan terapi farmakologis. Penatalaksanaan emesis pada kehamilan tergantung pada beratnya gejala. Pengobatan dapat dilakukan dengan cara farmakologi maupun nonfarmakologi. Terapi farmakologi dilakukan dengan pemberian antiemetik, antihistamin, anti kolinergik, dan kortikosteroid, namun ibu hamil akan lebih baik jika mampu mengatasi masalah mual pada awal kehamilan dengan menggunakan terapi pelengkap nonfarmakologis. Terapi nonfarmakologis bersifat noninstruktif, noninfasif, murah, sederhana, efektif, dan tanpa efek samping yang merugikan. Terapi nonfarmakologi dapat dilakukan dengan cara pengaturan diet, dukungan emosional, akupuntur, dan pemberian aroma terapi (Wiknjosastro, 2007).

Aroma terapi lemon adalah minyak essensial yang dihasilkan dari ekstrak kulit jeruk (Citrus Lemon) yang sering digunakan dalam aroma terapi. Aroma terapi lemon adalah jenis aroma terapi yang aman untuk kehamilan dan melahirkan (Medforth et al., 2013). Aroma terapi lemon memiliki kandungan yang dapat membunuh bakteri meningokokus (meningococcus), bakteri tipus, memiliki efek anti jamur dan efektif untuk menetralisir bau yang tidak menyenangkan, serta menghasilkan efek anti cemas, anti depresi, anti stres, dan untuk mengangkat dan memfokuskan pikiran. (Saridewi, 2018).

Komplikasi kehamilan berdampak sangat besar terhadap kesehatan ibu hamil, bahkan jika komplikasi kehamilan tidak dideteksi secara dini maka dapat mengakibatkan kematian ibu dan janin. Dampak komplikasi yang biasa atau umum terjadi misalnya preeklampsia. Preeklampsia dapat menyebabkan bayi BBLR. Preeklampsia adalah penyakit dengan tanda - tanda hipertensi, edema dan proteinuria yang timbul karena kehamilan. (Amiruddin, 2014).

Minyak esensial Lemon merupakan minyak herbal yang paling banyak digunakan dan dianggap sebagai obat yang aman pada kehamilan. Aromaterapi lemon terbukti memiliki efek menguntungkan pada emesis gravidarum.

Menurut penelitian Kia (2013) skor ratarata emesis gravidarum menurun selama empat hari menggunakan aromaterapi lemon inhalasi. Hal ini juga sesuai dengan penelitian yang dilakukan oleh Erick et al dengan melakukan pengamatan penggunaan perawatan nonfarmakologis pada wanita untuk menghilangkan emesis gravidarum.

Berdasarkan hasil penelitian tersebut menunjukkan bahwa $40 \%$ wanita menggunakan aroma lemon untuk meredakan mual muntah, dan lebih dari setengah dari 
mereka yang pernah menggunakannya mengatakan cara tersebut efektif.

Hasil survey pendahuluan yang dilakukan pada bulan akhir November 2019 di BPM Indra Iswari, SST, SKM, MM pada 5 ibu hamil trimester I yang melakukan pemeriksaan kehamilan didapatkan data bahwa sebanyak 4 orang $(80 \%)$ mengalami emesis dan satu orang (20\%) tidak mengalami emesis. Data hasil wawancara pada $10 \mathrm{ibu}$ hamil yang mengalami mual muntah didapatkan sebanyak 4 ibu hamil telah melakukan penanganan mual muntah menggunakan aroma terapi yaitu minyak kayu putih dan 6 ibu hamil mengatakan tidak menggunakan aromaterapi.

Berdasarkan latar belakang diatas maka peneliti tertarik untuk meneliti tentang "Efektivitas Pemberian Aromaterapi Lemon terhadap Penurunan Frekuensi emesis gravidarum pada Ibu Hamil Trimester I di BPM Indra Iswari, SST, SKM, MM"

Manfaat penelitian ini, diharapkan dapat memberikan informasi serta dapat menambah pengetahuan serta wawasan keilmuan dan penelitian ini diharapkan dapat memberikan informasi serta dapat menambah pengetahuan serta wawasan keilmuan belajar mahasiswa tentang pemberian aromaterapi lemon terhadap penurunan frekuensi emesis gravidarum pada ibu hamil trimester I. Tujuan dari penelitian ini adalah Untuk mengetahui efektivitas pemberian aromaterapi lemon terhadap penurunan frekuensi emesis gravidarum pada ibu hamil trimester I di BPM Indra Iswari, SST, SKM, MM.

\section{METODE PENELITIAN}

Penelitian ini merupakan penelitian analitik dengan rancangan cross sectional adalahh suatu penelitian untuk mempelajari dinamika kolerasi antara faktor - faktor resiko dengan efek, dengan cara pendekatan, observasi atau pengumpulan data sekaligus pada suatu saat (point time approach). (Sujarweni, 2014) Dimana variabel independentnya (bebas) adalah Aromaterapi lemon. Sedangkan variabel dependentnya adalah emesis Gravidarum.

Definisi operasional adalah variabel penelitian dimaksudkan untuk memahami arti setiap variabel penelitian sebelum dilakukan analisis. (Rajab, 2009) Definisi operasional dalam penelitian ini adalah sebagai berikut:

1. Penurunya Intensitas Emesis Gravidarum pada Ibu Hamil Trimester I adalah Penurunan Intensitas Mual Muntah pada ibu Hanil trimester I setelah pemberian aroma terapi lemon. Alat ukur yang digunakan untuk mengukur intensitas mual muntah ibu hamil menggunakan rhodes index nausea, comiting and retching (Rhodes INVR) yang terdiri dari 8 pertanyaan 3 pertanyaan untuk mengukur mual dan 5 pertanyan untuk mengukur muntah yang diisi oleh responden. Skala ukur yang digunakan adalah interval. Hasil ukur adalah Skor mual muntah merupakan penjumlahan skor dari 8 pertanyaan tentang mual muntah yang berkisar dari 0 -32, 0 : tidak mual muntah, 1-8: Mual muntah ringan, 9-16: Mual Muntah Sedang, 17-24: mual muntah berat, 25-32: mual muntah parah

2. Aromaterapi lemon merupakan metode yang digunakan peneliti untuk menurunkan intensitas mual muntah pasien. Peneliti melakukan pemberian aromaterapi lemon dengan cara inhalasi. Populasi adalah wilayah generalisasi yang terdiri atas objek, subjek yang mempunyai kualitas dan karakteristik tertentu yang di tetapkan oleh peneliti untuk di pelajari dan kemudian ditarik kesimpulannya (Hidayat, 2007). Populasi yang digunakan dalam penelitian ini adalah ibu hamil yang melakukan kunjungan ANC di BPM Indra Iswari, SST, SKM, MM. Sampel adalah sebagian dari populasi yang akan diteliti atau sebagian dari jumlah dari karakteristik yang dimiliki oleh populasi (Hidayat, 2007). 


\section{Kriteria Sampel:}

1. Kriteria inklusi adalah persyaratan umum yang harus dipenuhi oleh subyek penelitian/populasi agar dapat diikutsertakan dalam penelitian. Criteria inklusi dalam penelitian ini adalah:

a. Ibu hamil Trimester I

b. Ibu hamil yang mengalami Mual Muntah

c. Ibu Hamil yang bersedia menjadi responden

2. Kriteria eksklusi merupakan kriteria dimana subjek penelitian tidak dapat mewakili sampel karena tidak memenuhi syarat sebagai sampel penelitian. kriteria eksklusi dalam penelitian ini adalah:

a. Ibu hamil bukan Trimester I

b. Ibu hamil yang tidak mengalami Mual Muntah

a. Ibu Hamil yang tidak bersedia menjadi responden.

Pada penelitian ini teknik pengumpulan data dengan menggunakan data primer, instrumen yang digunakan dalam pengumpulan data adalah ibu yang datang melakukan kunjungan ANC di BPM Indra Iswari, SST, SKM, MM.

Analisa univariat digunakan untuk melihat distribusi frekuensi masing - masing variabel yang diteliti, baik variabel independent maupun variabel dependent. Analisa data diolah menggunakan sistem komputerisasi. Dalam penelitian ini analisa data berupa analisa univariat dan analisa bivariat. Analisa univariat yaitu bertujuan untuk menjelaskan atau mendeskripsikan setiap variabel penelitian (Notoatmodjo, 2010). Analisis bivariat dilakukan untuk mengetahui antara variabel dependen dan independen di BPM Indra Iswari, SST, SKM, MM Kota Bengkulu dengan menggunakan uji statistik uji Wilxocon Sign Rank Test ada tidaknya hubungan yang dilihat dari hasil analisis (Nilai $x^{2}$ dan $p$ - value), dengan menggunakan komputer program SPSS dengan tingkat kepercayaan 95\% (Sujarweni,
2014). Hasil Chi-square dapat dilihat pada kotak Chi-square test, dengan aturan yang berlaku:

1. Bila ada tabel $2 \times 2$ dijumpai nilai expected (harapan) $<5$, maka yang digunakan adalah fishers's exact test

2. Bila tabel $2 \times 2$ tidak dijumpai atau tidak ada nilai expacted (harapan) $<5$, maka yang digunakan adalah continuity correction

3. Bila tabelnya lebih dari $2 \times 2$ misalnya $2 \times 3$, $3 \times 3$, dll, maka digunakan uji pearson Chisquare, dengan kriteria (Riyanto, 2009):

a. Ha diterima : jika $\mathrm{p} \leq 0,05$ maka secara statistik ada hubungan bermakana

b. Ha ditolak : jika $p>0,05$ maka secara statistik tidak ada hubungan bermakna.

\section{HASIL PENELITIAN}

Berikut ini adalah hasil penelitian yang dilakukan di BPM Indra Iswari, SST, SKM, MM untuk mengetahui distribusi frekuensi dari masing - masing variabel yang diteliti.

Tabel 1. Distribusi Frekuensi Karakteristik Responden Berdasarkan Pekerjaan, Pendidikan, Paritas. Umur dan Usia Kehamilan Ibu Hamil Trimester I di BPM Indra Iswari, SST, SKM, MM

\begin{tabular}{c|c|c}
\hline Variabel & $\begin{array}{c}\text { Frekuensi } \\
\text { (F) }\end{array}$ & $\mathbf{( \% )}$ \\
\hline Pekerjaaan & 9 & $60.0 \%$ \\
Bekerja & 6 & $40.0 \%$ \\
Tidak Bekerja & & \\
Pendidikan & 1 & $6.7 \%$ \\
SD & 0 & $0 \%$ \\
SMP & 6 & $40.0 \%$ \\
SMA & 8 & $53.3 \%$ \\
Perguruan Tinggi & & \\
Paritas & 12 & $80.0 \%$ \\
Primipara & 5 & $20.0 \%$ \\
Multipara & & \\
\hline
\end{tabular}




\begin{tabular}{c|c|c}
\hline Umur & 10 & \\
$20-30$ & 5 & $66.7 \%$ \\
$31-35$ & & $33.3 \%$ \\
\hline
\end{tabular}

Sumber: Olah data komputerisasi 2020

Berdasarkan tabel 1 menunjukkan sebagian besar responden berstatus bekerja sebanyak 9 orang $(60 \%)$. Pendidikan responden sebagian besar Perguruan Tinggi sebanyak 8 orang $(53.3 \%)$. Paritas responden sebagian besar adalah primipara sebanyak 12 orang (80\%). Umur responden sebagian besar adalah 20-30 tahun sebanyak 10 orang (66.7\%).

Tabel 2. Distribusi frekuensi Tingkat Mual Muntah sebelum diberikan Aromaterapi Lemon di BPM Indra Iswari, SST, SKM, MM

\begin{tabular}{c|c|c}
\hline $\begin{array}{c}\text { Tingkat Mual dan } \\
\text { Muntah }\end{array}$ & $\begin{array}{c}\text { Frekuensi } \\
(\mathbf{F})\end{array}$ & $\mathbf{( \% )}$ \\
\hline Pekerjaaan & & \\
Tidak Mual dan Muntah & 0 & $0 \%$ \\
Ringan & 0 & $0 \%$ \\
Sedang & 13 & $86.7 \%$ \\
Berat & 2 & $13.3 \%$ \\
\hline
\end{tabular}

Sumber: Olah data komputerisasi 2020

Berdasarkan tabel 2 menunjukkan tingkat mual dan muntah sebelum diberikan aromaterapi Lemon pada ibu hamil trimester I di BPM Indra Iswari, SST, SKM, MM sebagian besar adalah kategori sedang sebanyak 13 orang $(86,7 \%)$.

Tabel 3. Distribusi frekuensi Tingkat Mual Muntah setelah diberikan Aromaterapi Lemon di BPM Indra Iswari, SST, SKM, MM

\begin{tabular}{c|c|c}
\hline $\begin{array}{c}\text { Tingkat Mual dan } \\
\text { Muntah }\end{array}$ & $\begin{array}{c}\text { Frekuensi } \\
(\mathbf{F})\end{array}$ & $\mathbf{( \% )}$ \\
\hline Pekerjaaan & & \\
Tidak Mual dan Muntah & 0 & $0 \%$ \\
Ringan & 13 & $86.7 \%$ \\
Sedang & 2 & $13.3 \%$ \\
Berat & 0 & $0 \%$ \\
\hline
\end{tabular}

Sumber: Olah data komputerisasi 2020

Tabel 4 menunjukkan tingkat mual dan muntah setelah diberikan aromaterapi Lemon pada ibu hamil trimester I di BPM Indra Iswari, SST, SKM, MM sebagian besar adalah kategori ringan sebanyak 13 orang $(86,7 \%)$.

Berdasarkan tabel 4 Hasil perhitungan statistik menggunakan uji Wilxocon Sign Rank Test seperti disajikan pada tabel 5.4 diperoleh p-value sebesar sebesar $0,001<\mathrm{a}$ $(0,05)$, artinya ada pengaruh aromaterapi Lemon terhadap mual dan muntah pada ibu.

\section{PEMBAHASAN}

\section{Analisis Univariat}

Karakteristik responden sebagian besar responden berstatus bekerja sebanyak 9 orang $(60 \%)$ juga bisa berpengaruh terhadap kejadian mual muntah. Hal ini sejalan dengan penelitian yang dilakukan oleh Armilah, (2010) yang mengungkapkan bahwa ibu yang bekerja lebih besar risikonya terhadap kejadian hiperemesis gravidarum dibandingkan dengan ibu yang tidak bekerja. Sedangkan pekerjaan yang berisiko tinggi antara lain adalah pelayan toko, pelayan departement store, pekerja kantor, karyawan pabrik, petani (Ismail, 2010 dalam Anasari, 2012).

Pendidikan responden sebagian besar Perguruan Tinggi sebanyak 8 orang (53.3\%). Kejadian mual muntah juga dapat dipengaruhi oleh paritas ibu hamil yang sebagian besar adalah primipara sebanyak 12 orang $(80 \%)$. Hal ini sesuai dengan pendapat Winkjosastro, (2007) yang mengungkapkan bahwa ibu primigravida belum mampu beradaptasi terhadap hormon estrogen dan khorionik gonadotropin. Peningkatan hormon ini membuat kadar asam lambung meningkat, hingga muncullah keluhan rasa mual. Keluhan ini biasanya muncul di pagi hari saat perut ibu dalam keadaan kosong dan terjadi peningkatan asam lambung.

Hasil ini didukung oleh penelitian Umboh (2014) yang menunjukkan adanya hubungan yang bermakna antara paritas dengan kejadian Hiperemesis Gravidarum 
pada Ibu Hamil di Puskesmas Tompaso Kabupaten Minahasa Induk.

Umur responden sebagian besar adalah 20-30 tahun sebanyak 10 orang (66.7\%). Penelitian yang dilakukan Misbah (2014) menunjukkan bahwa ibu hamil yang berumur 20-35 tahun paling banyak menderita emesis gravidarum dibandingkan yang tidak mengalami emesis gravidarum.

\section{Analisis Bivariat}

Tingkat mual dan muntah diberikan aromaterapi kategori ringan sebanyak 13 orang $(86.7 \%)$. Ibu hamil yang sebelumnya mengalami mual dan sebagian besar mengalami mual dan muntah kategori sedang sebanyak 2 orang (13.3\%). Hasil penelitian ini sesuai dengan wardani (2019) yang menunjukkan rata-rata frekuensi hiperemesis gravidarum pada ibu hamil di kecamatan Natar Kabupaten Lampung Selatan sebelum pemberian aromaterapi Lemon dan saat pemberian aromaterapi lemon mengalami penurunan.

Dari hasil penelitian ini diperoleh hasil uji Wilxocon Sign Rank Test diperoleh pvalue sebesar $0,001<\mathrm{a}(0,05)$, artinya ada pengaruh aromaterapi lemon terhadap mual dan muntah pada ibu hamil trimester I di BPM Indra Iswari, SST, M.Kes. Hasil penelitian ini sesuai dengan Wardani (2019) yang menemukan adanya pengaruh pemberian essensial Lemon terhadap intensitas mual dan muntah pada ibu hamil trimester I.

Berdasarkan analisis menggunakan $\mathrm{GC}-$ MC (Gas Chromatography-Mass Spectrometry) mengandung 5 komponen berfungsi sebagai anti mual muntah. Komponen tersebut diantaranya yaitu Limonene (5,96\%), cis-Dihydrocarvone $(19,19 \%)$, Pulegone $(13,30 \%)$, Carvone (42,53\%), B-Caryphyllene (6,78\%) (Najaran et al., 2013).

Aroma terapi merupakan tindakan terapeutik dengan menggunakan minyak essensial yang bermanfaat untuk meningkatkan keadaan fisik dan psikologi sehingga menjadi lebih baik. Setiap minyak essensial memiliki efek farmakologis yang unik, seperti antibakteri, antivirus, diuretik, vasodilator, penenang, dan merangsang adrenal. Ketika minyak essensial dihirup, molekul masuk ke rongga hidung dan merangsang sistem limbik di otak. Sistem limbik adalah daerah yang memengaruhi emosi dan memori serta secara langsung terkait dengan adrenal, kelenjar hipofisis, hipotalamus, bagian-bagian tubuh yang mengatur denyut jantung, tekanan darah, stess, memori, keseimbangan hormon, dan pernafasan Runiari (2010).

\section{KESIMPULAN}

Berdasarkan hasil penelitian tentang efektivitas pemberian aromaterapi lemon terhadap penurunan frekuensi emesis gravidarum pada ibu hami trimester I di BPM Indra Iswari, SST, SKM, MM dapat disimpulkan:

1. Tingkat mual muntah sebelum diberikan aromaterapi lemon pada ibu hamil trimester I sebagian besar adalah kategori sedang $86.7 \%$.

2. Tingkat mual muntah setelah diberikan aromaterapi lemon pada ibu hamil trimester I sebagian besar adalah kategori sedang $86.7 \%$.

3. Ada pengaruh aromaterapi Lemon terhadap mual dan muntah pada ibu hamil trimester I di BPM Indra Iswari, SST, SKM, MM, ditunjukkan dengan hasil uji Wilcoxon diperoleh $p$-value $0,001<0,05$.

\section{SARAN}

Bagi peneliti selanjutnya diharapkan untuk mengkaji lebih lanjut lagi mengenai efektivitas pemberian aromaterapi lemon terhadap penurunan frekuansi emesis gravidarum pada ibu hamil trimester I di BPM Indra Iswari, SST, SKM, MM. 


\section{DAFTAR PUSTAKA}

Alankar, S. (2009). A Review On Peppermint Oil. Asian Journal of Pharmaceutical and Clinical Research.Volume 2, Issue 2, April -June, 2009.

Anasari, T. (2012). Beberapa Determinan Penyebab Kejadian Hiperemesis Gravidarum di RSU Ananda Purwekwrto Tahun 20092011. Jurnal Involusi Kebidanan. 2 (4). 63.

Aril, C.Y.A. (2012). Hubungan Antara Karakteristik Ibu Hamil dengan Kejadian Hiperemesis Gravidarum di RSUD Ujungberung Pada Periode 2010-2011

Misbah, N (2014). Hubungan Paritas dan Umur Ibu dengan Kejadian Hiperemesis Gravidarum di RSUD Adjidarmo Rangkasbitung 2011. Jurnal Kebidanan

Notoatmodjo. 2010. Metodologi Penelitian Kesehatan. Jakarta:Penerbit Rineka Cipta

Parwitasari, D. C., Utami, S.,Rahmalia. S. (2014). Efektifitas Pemberian Rebusan Jahe dan Daun Mint Terhadap Mual Muntah pada Ibu Hamil. hlm 2.

Pudiastuti, R. D. (2012). Asuhan Kebidanan pada Ibu Hamil Normal dan Patologi. Yogyakarta: Nuha Medika

Rajab, Wahyudin. 2009. Buku Ajar Epidemiologi untuk Mahasiswa Kebidanan. Jakarta: EGC

Saifuddin. 2010. Pelayanan Kesehatan Maternal dan Neonatal. Jakarta: PT Bina Pustaka Sarwono Prawirohardjo

Santi, R.D (2013). Pengaruh Aromaterapi Peppermint dan Ginger Oil terhadap Rasa Mual pada Ibu Hamil Trimester Satu di Puskesmas Rengel Kabupaten Tuban, Jurnal Sain Med. 5 (2). 52-55.

Solikhah, U. (2011). Asuhan Keperawatan: Gangguan Kehamilan, Persalinan, an Nifas. Yogyakarta: Nuha Medika.

Sujarweni. 2014. Metodologi Penelitian Keperawatan. Yogyakarta; Pustaka Baru Press

Tharpe, N. L., Farley, L. C., \& Jordan, R. G. (2014). Clinical Practice Guidelines for Midwifery \& Women's Health. Burlington: Kevin Sullivan.
Tiran, D. (2008). Mual dan Muntah Kehamilan: Seri Asuhan Kebidanan. Jakarta: EGC.

Umboh , H. S., Mamuaya, T., \& Lumy, F. S. (2014). Faktor-faktor Yang Berhubungan Dengan Kejadian Hiperemesis Gravidarum Di Puskesmas Tompaso Kabupaten Minahasa. Jurnal Kebidanan. 2 (2). 30.

Wiknjosastro, H. (2007). Ilmu kebidanan. Jakarta: Yayasan Bina Pustaka Sarwono Prawiroharjo.

Yantina, Y. (2016). Pengaruh Pemberian Essensial Oil Peppermint Terhadap Intensitas Mual dan Muntah pada Ibu Hamil Trimester I di Desa Way Harong Timur Kecamatan Way Lima Kabupaten Pesawaran, Jurnal Kebidanan 2 (4).194199 